\title{
Iron deficiency in Yemeni patients with sickle-cell disease
}

\author{
A. Kassim, ${ }^{1}$ S. Thabet, ${ }^{7}$ M. Al-Kabban ${ }^{2}$ and K. Al-Nihari ${ }^{3}$
}

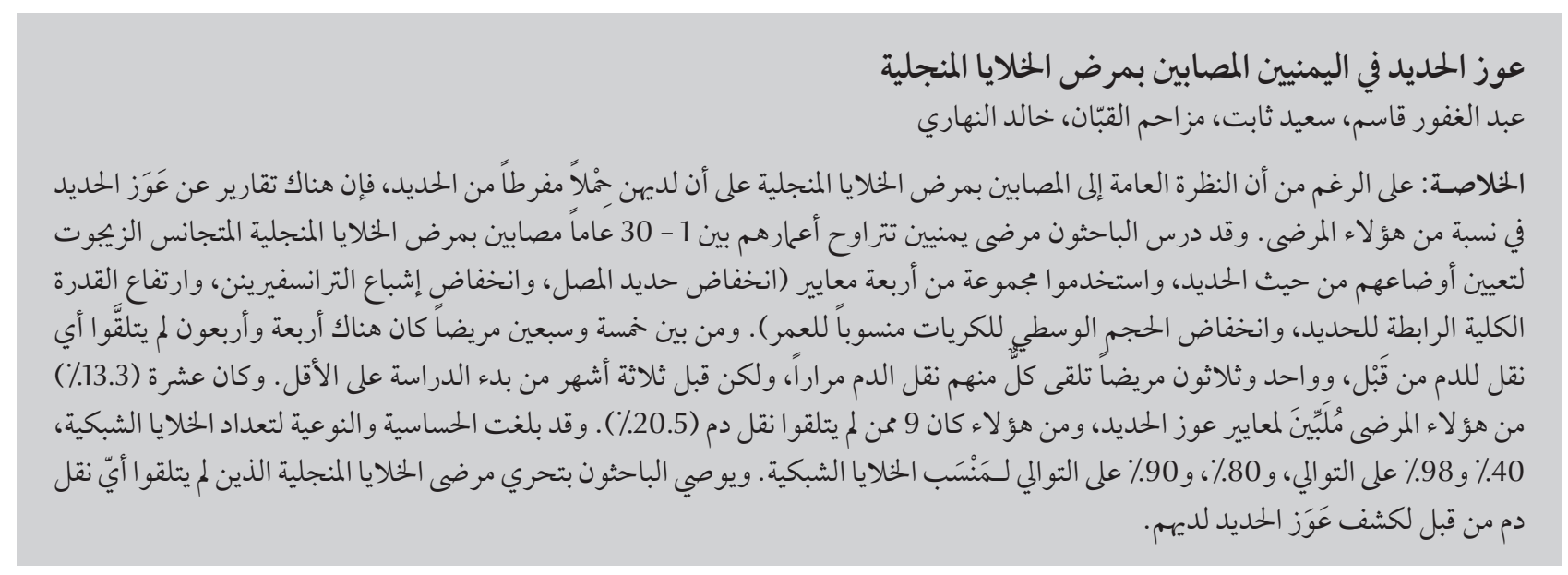

ABSTRACT Despite the general view that patients with sickle-cell disease (SCD) have iron overload, there are reports of iron deficiency in a proportion of these patients. We studied Yemeni patients aged 1-30 years with homozygous SCD to determine their iron status using a set of 4 criteria (low serum iron, low transferrin saturation, high total iron binding capacity and low mean corpuscular volume for age). Of the 75 patients, 44 had never been transfused while 31 patients had received blood transfusions but not during the 3-month period prior to the study. Of the patients, 10 (13.3\%) met the criteria for iron deficiency, 9 of whom were from the non-transfused patients (20.5\%). The sensitivity and specificity were $40 \%$ and $98 \%$ respectively for reticulocyte count and $80 \%$ and $90 \%$ respectively for reticulocyte index. We recommend screening non-transfused SCD patients for iron deficiency.

\section{Anémie ferriprive chez des patients yéménites atteints de drépanocytose}

RÉSUMÉ En dépit de l'idée communément admise selon laquelle les patients atteints de drépanocytose souffrent d'une surcharge en fer, certains d'entre eux sont atteints d'une anémie ferriprive. Nous avons examiné des patients yéménites âgés de 12 mois à 30 ans atteints de drépanocytose homozygote afin d'établir leur bilan en fer à l'aide de quatre critères (taux de fer sérique faible, taux de saturation de la transferrine faible, capacité totale de fixation du fer élevée et volume globulaire moyen faible par rapport à l'âge). Sur 75 patients, 44 n'avaient jamais été transfusés, 31 avaient reçu des transfusions sanguines mais pas dans les trois mois précédents l'étude. Parmi les patients, 10 (13,3\%) ont reçu le diagnostic d'anémie ferriprive, dont 9 appartenaient au groupe de patients n'ayant jamais été transfusés (20,5\%). La sensibilité et la spécificité étaient de $40 \%$ et $98 \%$ respectivement pour la numération des réticulocytes et de $80 \%$ et $90 \%$ respectivement pour l'indice de production des réticulocytes. Nous recommandons le dépistage de l'anémie ferriprive chez les patients drépanocytaires n'ayant jamais été transfusés.

${ }^{7}$ Department of Internal Medicine; ${ }^{2}$ Department of Medical Biochemistry, Faculty of Medicine, University of Taiz, Taiz, Yemen (Correspondence to A. Kassim:taizmedicine@yemen.net.ye).

${ }^{3}$ Yemen Blood Diseases Friends'Society, Taiz, Yemen.

Received: 12/01/09; accepted: 26/04/09 


\section{Introduction}

It is generally believed that patients with severe inherited haemolytic anaemia have a state of iron overload, owing to increased bioavailability of iron from haemolysed red blood cells (RBCs), blood transfusions and increased iron absorption in the gut in haemolysis [1]. Therefore in sickle-cell disease (SCD), microcytosis - defined by low mean corpuscular volume (MCV) and low mean corpuscular haemoglobin - indicates an association with $\alpha$ - and $\beta$-thalassaemia rather than iron deficiency $[2,3]$. In this context iron deficiency is considered unlikely and prescription of iron preparations to these patients is commonly avoided in clinical practice.

Iron deficiency is considered the leading cause of anaemia worldwide, especially in children and adult women [4-6]. In countries with low socioeconomic status iron deficiency is common $[4,7]$ and the higher iron requirements in growing children are jeopardized due to factors such as low dietary intake of iron and high helminth burden. Patients with SCD may have similar conditions and in addition may have excessive urinary loss of iron [3]. The identification of iron deficiency in SCD is important, particularly in growing children, as it contributes to the severity of anaemia [3] and has negative consequences on a child's physical and mental development [8]. Worldwide, few studies have been performed on iron status in SCD and none in Yemen. The present study was conducted to determine the iron status of Yemeni patients with SCD.

\section{Methods}

\section{Patients}

A total of 75 patients with homozygous SCD, aged $1-30$ years [mean age 11.2 (SD 7.6) years] attending the medical centre of the Yemen Blood Diseases Friends' Society in Taiz governorate, a nongovernmental organization working in cooperation the Ministry of Health, during the period between June 2007 and June 2008 were included in the study: 38 males and 37 females. Of the 75 patients 44 had never been transfused while 31 patients had previously received blood transfusions but not during the 3-month period prior to obtaining blood samples and inclusion in the study.

\section{Data collection}

The diagnosis of SCD was established by haemoglobin electrophoresis using cellulose acetate paper $\mathrm{pH} 8.2$ as the screening method [9] and confirmed by high-performance liquid chromatography (Bio-Rad D 10 Herculis) [10]. Haematological parameters were determined using a Coulter counter (Sysmex KX-21N). Serum iron level and iron binding capacity were determined colorimetrically (Spinreact kits) and the saturation-precipitation method was used for total iron binding capacity (TIBC).

The reticulocyte count was determined from prepared smears after staining of blood with methylene blue and reported as the percentage of circulating RBCs [1]. The reticulocyte index is the reticulocyte count corrected for haemoglobin according to the following formula:

Reticulocyte index $=(\%$ reticulocytes $\times$ patient's $\mathrm{Hb}$ )/normal $\mathrm{Hb}$

In anaemic patients a reticulocyte index $\geq 3$ indicates an appropriate bone marrow response as in blood loss or haemolysis, while a reticulocyte index $\leq 2$ is usually taken to indicate inadequate bone marrow response (hypoproliferation). In our study we used the more rigid criterion of $<1$ for diagnosis of impaired erythropoiesis and for calculating the sensitivity and specificity compared with the other criteria used in the diagnosis of iron deficiency.
The diagnosis of iron deficiency was established if all the following 4 criteria were present: low serum iron $<45 \mu \mathrm{g} /$ dL [1], low transferrin saturation (TS) $<16 \%$ [1], high TIBC $\geq 450 \mu \mathrm{g} / \mathrm{dL}$ [1] and low MCV for age: $0.5-2$ years $<70$ $\mathrm{fL}, 2-5$ years $<73 \mathrm{fL}, 5-9$ years $<75 \mathrm{fL}$, 9-14 years $<76 \mathrm{fL}, 14-18$ years $<77 \mathrm{fL}$, $18+$ years $<80 \mathrm{fL}[11]$. Serum ferritin was not included because at the time of the study suitable assays were unavailable in the laboratories of the Faculty of Medicine and it was expensive to perform at private laboratories.

\section{Statistical analysis}

Student $t$-test and 1-way analysis of variance were used to compare means. Statistical significance was accepted when $P$ values were $<0.05$. Data analysis was made on a personal computer using SPSS, version 15.0.

\section{Results}

The initial laboratory data of all $75 \mathrm{pa}-$ tients, divided into 2 groups according to transfusion history in the transfused and non-transfused group are shown in Table 1 . There were no statistically significant differences between the groups in any of the parameters measured.

Of the total 75 patients 10 (13.3\%) ( 6 males and 4 females) met the criteria for iron deficiency. The age, haematological and biochemical data of these iron-deficient patients are shown in Table 2. Of these 10 patients 9 were from the non-transfused group $(n=44$, $20.5 \%)$ and only 1 was from the transfused group $(n=31,3.2 \%)$. The patient identified with iron deficiency from the transfused group was a female, aged 25 years with 3 pregnancies (case 9). She had a transfusion history of 2 units of blood on 2 different occasions, but the amount of iron given by transfused blood was judged to be too little to have influenced her iron status significantly.

The mean values of age and the haematological and biochemical 


\begin{tabular}{|c|c|c|}
\hline \multicolumn{3}{|c|}{$\begin{array}{l}\text { Table } 1 \text { Haematological and biochemical parameters of the } 75 \text { patients with } \\
\text { sickle-cell disease by transfusion history }\end{array}$} \\
\hline Variable & $\begin{array}{c}\text { Transfused } \\
(n=31) \\
(M=12 ; \mathrm{F}=19)\end{array}$ & $\begin{array}{l}\text { Non-transfused } \\
(n=44) \\
(M=27 ; \mathrm{F}=17)\end{array}$ \\
\hline & Mean (SD) & Mean (SD) \\
\hline Age (years) & $12.9(22.2)$ & $10.1(2.0)$ \\
\hline Haemoglobin (g/L) & $75.7(22.2)$ & $78.7(18.1)$ \\
\hline Reticulocyte count (\%) & $12.1(12.0)$ & $8.3(6.9)$ \\
\hline $\operatorname{MCV}(\mathrm{fL})$ & $79.4(13.7)$ & $77.0(8.9)$ \\
\hline Serum iron $(\mu \mathrm{g} / \mathrm{dL})$ & $143.6(89.9)$ & $105.4(96.9)$ \\
\hline TS (\%) & $92.9(92.3)$ & $70.5(112.6)$ \\
\hline $\operatorname{TIBC}(\mu \mathrm{g} / \mathrm{dL})$ & $203.6(109.0)$ & $272.4(178.5)$ \\
\hline
\end{tabular}

$n=$ number of patients; $M=$ number of males; $F=$ number offemales; $S D=$ standard deviation. $M C V=$ mean corpuscular volume; $T S=$ transferrin saturation; $T I B C=$ total iron binding capacity.

parameters of the 10 iron-deficient and 65 non-iron-deficient patients ( 30 with and 35 without transfusion history) are shown in Table 3. The age of iron deficiency patients ranged from $5-30$ years with a mean of 16.3 years. The reticulocyte count in the irondeficiency patients ranged from $0 \%$ to $7 \%$ with a mean of $2.5 \%$ (Table 3 ) and the calculated reticulocyte index, corrected for haemoglobin, ranged between 0 and 2.10 with a mean of 0.66 . The mean value of the reticulocyte count of the iron-deficient patients $(2.5 \%)$ was significantly lower than those of the non-iron-deficient patients $(9.7 \%$ in the non-transfused and $12.5 \%$ in the transfused group) ( $P$ $<0.05$ ).

There were no statistically significant differences in the mean haemoglobin level between the iron-deficient and non-iron-deficient patients $(P=0.234)$. The mean reticulocyte count, MCV, serum iron and TS levels were significantly lower in iron-deficient patients than in non-iron-deficient patients (non-transfused and transfused) $(P<$ $0.05)$ and the mean TIBC was significantly higher in iron-deficient than in non-iron-deficient patients $(P<0.001)$.

The sensitivity and specificity of the reticulocyte count and reticulocyte index compared with our 4 criteria for the diagnosis of iron deficiency in SCD patients are shown in Table 4. Using a more rigid criterion for diagnosis of impaired erythropoiesis (cut-off $<1 \%$ ) the reticulocyte count showed a sensitivity of only $40 \%$ and the reticulocyte index showed a sensitivity of $80 \%$. Meanwhile the specificity of both reticulocyte count and reticulocyte index were as high as $98 \%$ and $90 \%$ respectively.

\section{Discussion}

Although the medical literature tends to support the view that patients with SCD have iron overload $[12,13]$, there are contrary reports that describe iron deficiency in a proportion of these patients $[2-4,7,14]$. The diagnosis of iron deficiency in patients with SCD is difficult because there is no highly specific test to define iron status in such patients $[4,15]$, and as the reliability of the conventional laboratory tests used for the diagnosis of iron-deficiency anaemia may be modified by SCD as well as by other factors such as inflammation and age [4]. Therefore it has been proposed that the use of a battery of tests to define iron status in a population improves the precision in diagnosis of iron-deficiency anaemia $[4,15]$. In our study we used 4 criteria to identify iron deficiency in 44 non-transfused and 31

\begin{tabular}{|c|c|c|c|c|c|c|c|c|c|}
\hline Patient no. & Sex & $\begin{array}{c}\text { Age } \\
\text { (years) }\end{array}$ & $\begin{array}{l}\mathrm{Hb} \\
(\mathrm{g} / \mathrm{L})\end{array}$ & $\begin{array}{l}\text { Retic count } \\
\text { (\%) }\end{array}$ & Retic index & $\begin{array}{c}\text { MCV } \\
\text { (fL) }\end{array}$ & $\begin{array}{c}\text { Serum iron } \\
(\mu \mathrm{g} / \mathrm{dL})\end{array}$ & $\begin{array}{l}\text { TIBC } \\
(\mu \mathrm{g} / \mathrm{dL})\end{array}$ & $\begin{array}{l}\text { TS } \\
(\%)\end{array}$ \\
\hline 1 & $M$ & 5 & 57 & 6 & 1.22 & 68.8 & 41.4 & 483 & 8.6 \\
\hline 2 & M & 8 & 35 & 1 & 0.13 & 71.0 & 29.0 & 520 & 5.5 \\
\hline 3 & $M$ & 12 & 86 & 3 & 0.92 & 70.0 & 27.1 & 510 & 5.3 \\
\hline 4 & M & 14 & 68 & 2 & 0.49 & 69.2 & 40.0 & 540 & 7.4 \\
\hline 5 & M & 14 & 77 & 0 & 0.00 & 69.0 & 29.0 & 499 & 5.9 \\
\hline 6 & $\mathrm{~F}$ & 15 & 92 & 1 & 0.33 & 68.0 & 20.0 & 480 & 4.1 \\
\hline 7 & $\mathrm{~F}$ & 17 & 91 & 2 & 0.65 & 69.0 & 25.8 & 450 & 5.8 \\
\hline 8 & M & 23 & 84 & 7 & 2.10 & 72.0 & 38.5 & 490 & 7.8 \\
\hline 9 & $\mathrm{~F}$ & 25 & 63 & 1 & 0.23 & 72.0 & 43.5 & 498 & 8.7 \\
\hline 10 & $\mathrm{~F}$ & 30 & 70 & 2 & 0.50 & 75.0 & 27.9 & 470 & 5.9 \\
\hline Mean (SD) & & $16.3(7.7)$ & $72.3(17.7)$ & $2.5(2.3)$ & $0.66(0.63)$ & $70.4(2.1)$ & $32.3(7.9)$ & 494 (26) & $6.5(1.5)$ \\
\hline
\end{tabular}

$M=$ male $;=$ female $; S=$ standard deviation.

$\mathrm{Hb}=$ haemoglobin; retic = reticulocyte; $\mathrm{MCV}=$ mean corpuscular volume; $T I B C=$ total iron binding capacity; $T S=$ transferrin saturation . 


\begin{tabular}{|c|c|c|c|}
\hline \multirow[t]{3}{*}{ Variable } & \multirow{2}{*}{$\begin{array}{l}\text { Iron-deficient } \\
(n=10) \\
(M=6 ; \mathrm{F}=4)\end{array}$} & \multicolumn{2}{|c|}{ Non-iron-deficient } \\
\hline & & $\begin{array}{l}\text { Non-transfused } \\
\quad(n=35) \\
(M=21 ; F=14)\end{array}$ & $\begin{array}{c}\text { Transfused } \\
(n=30) \\
(M=12 ; F=18)\end{array}$ \\
\hline & Mean (SD) & Mean (SD) & Mean (SD) \\
\hline Age (years) & $16.3(7.7)$ & $8.7(5.8)$ & $12.5(8.4)$ \\
\hline Haemoglobin (g/L) & $72.3(17.7)$ & $80.1(18.0)$ & $76.2(22.5)$ \\
\hline Reticulocyte count (\%) & $2.5(2.3)^{*}$ & $9.7(6.9)$ & $12.5(12.0)$ \\
\hline Serum iron $(\mu \mathrm{g} / \mathrm{dL})$ & $32.3(7.9)^{*}$ & $124.6(100.1)$ & $147.0(89.5)$ \\
\hline $\mathrm{MCV}(\mathrm{fL})$ & $70.4(2.1)^{*}$ & $78.7(9.1)$ & $79.6(13.9)$ \\
\hline TS (\%) & $6.5(1.5)^{*}$ & $87.1(121.0)$ & $95.7(92.5)$ \\
\hline TIBC $(\mu \mathrm{g} / \mathrm{dL})$ & $494.0(25.7)^{*}$ & $215.6(145.5)$ & $193.8(95.9)$ \\
\hline
\end{tabular}

${ }^{*} P<0.05$ between iron-deficient and non-iron-deficient non-transfused and transfused patients. $n=$ number of patients; $M=$ number of males; $F=$ number offemales; $S D=$ standard deviation. $M C V=$ mean corpuscular volume; $T S=$ transferrin saturation; $T I B C=$ total iron binding capacity.

transfused homozygous SCD patients: low serum iron, low TS, high TIBC and low MCV for age.

A total of 10 patients (13.3\%) met the criteria for iron deficiency. As 9 of these were from the non-transfused group, the rate of iron deficiency among the 44 patients without transfusion history was $20.5 \%$. Iron deficiency in SCD patients was reported in other studies from different regions of the world. King et al. from Jamaica, using similar criteria for diagnosis as ours, identified iron deficiency in $8.5 \%$ of non-transfused SCD children aged $1-5$ years [4]. Das et al. from India reported iron deficiency in $23 \%$ of SCD patients [16], which is very close to our result. Meanwhile Mohanty et al. also from India, in a population-based study using the zinc protoporphyrin/haem ratio (ZPP/ haem) for diagnosis, reported $67.7 \%$ iron deficiency in SCD non-transfused patients [7], which is much higher than our rate and also higher than the 23\% rate previously reported from the same country [16]. In Nigeria, Okeahialam found depletion of iron stores in the bone marrow in $47 \%$ and low serum iron in 31\% of patients with SCD [14]. Finally, Vickinsky et al. in the United States [3] and Rao Nagaraj and Sur in India [17] found iron deficiency in SCD in $16 \%$ and $8 \%$ of patients respectively.
Different criteria were used for diagnosis of iron deficiency in these studies, ranging from using a single criterion such as iron stores in the bone marrow [14] or ZPP/haem [7] to using a combination of tests such as low MCV, serum iron, TIBC and TS [4]. This highlights the fact that there is not yet an agreed diagnostic marker for iron deficiency in SCD $[4,15]$. In the present study, because we diagnosed a state of iron deficiency if all 4 criteria were fulfilled, it is possible that some patients with iron deficiency who did not meet these criteria were misclassified as non-irondeficiency (false negative) and some patients with $\alpha$ - and $\beta$-thalassaemia were included in the iron-deficiency group (false positive). However, the risk of misclassification has no influence on the general conclusion that a state of iron deficiency may exist among nontransfused patients with SCD, and that this should be screened for and treated if demonstrated, regardless of haemoglobin level, because the haemoglobin level is usually low in SCD patients.

The reticulocyte count in our iron deficiency patients ranged from $0 \%$ to $7 \%$, with a mean of $2.5 \%$, and the calculated reticulocyte index corrected for haemoglobin ranged between 0 and 2.10 , with a mean of 0.66 . This is a sign of impaired erythropoiesis, which is known to be associated with many conditions including iron, folate and vitamin B12 deficiency and, when MCV is low for age, the reduced reticulocyte count/ index supports the diagnosis of iron deficiency in our patients. The mean

\section{Table 4 Sensitivity and specificity of the reticulocyte count and reticulocyte index compared with the 4 criteria used for the diagnosis of iron deficiency in patients with sickle-cell disease}

\begin{tabular}{lccc} 
Criteria & $\begin{array}{c}\text { Sensitivity } \\
(\%)\end{array}$ & $\begin{array}{c}\text { Specificity } \\
(\%)\end{array}$ & $\begin{array}{c}\text { Positive predictive } \\
\text { value (\%) }\end{array}$ \\
Serum iron $\leq 45 \mu \mathrm{g} / \mathrm{dL}$ & 100 & 88 & 53 \\
Low MCV for age & 100 & 71 & 27 \\
TS $\leq 16 \%$ & 100 & 97 & 83 \\
TIBC $\geq 450 \mu \mathrm{g} / \mathrm{dL}$ & 100 & 93 & 67 \\
Reticulocyte count $\leq 1 \%$ & 40 & 97 & 83 \\
Reticulocyte index $\leq 1$ & 80 & 90 & 59 \\
\hline
\end{tabular}

$M C V=$ mean corpuscular volume; $T S=$ transferrin saturation; $T I B C=$ total iron binding capacity . 
reticulocyte count in iron-deficiency patients in our study was significantly lower than in non-iron-deficient transfused and non-transfused patients $(P<$ $0.002)$. The reticulocyte count and the reticulocyte index are therefore important tests that should be considered in the evaluation of SCD patients, and when these are low in the presence of low MCV it is very suggestive of iron deficiency.

The sensitivity and specificity compared with the criteria used for the diagnosis of iron deficiency were $40 \%$ and $98 \%$ respectively for reticulocyte count and $80 \%$ and $90 \%$ respectively for reticulocyte index. This relatively low sensitivity in relation to specificity is expected with the rigid criteria used for diagnosis of bone marrow hypoproliferation. Therefore the low sensitivity of $40 \%$ for reticulocyte count was increased to $80 \%$ by using the reticulocyte index (i.e. correcting for $\mathrm{Hb}$ ) and the sensitivity of these tests may be further increased if a less rigid definition of bone marrow hypoproliferation were used (cut-off $<2$ ) as is the case for anaemic patients in the clinical setting.

The age of iron deficiency patients ranged from 5 and 30 years with a mean of 16.3, indicating that iron deficiency may be found in small children as well as in older children and in adults. This suggests that age has no predictive value for iron deficiency, which agrees with reports from other authors $[2,7]$ but not with the results of Vichinisky et al. in their case series in which all diagnosed iron deficiency patients were less than 5 years old [3]. They also established the diagnosis of iron deficiency in $6 \mathrm{SCD}$ patients following a response to a trial of oral iron therapy after initial screening for iron deficiency by the conventional laboratory tests such as RBC indices, serum iron, TIBC, TS and serum ferritin.

Oral iron therapy trial may constitute a practical way for confirmation of iron deficiency in non-transfused SCD patients and may be clinically useful in poor countries such as Yemen where
SCD is prevalent in some regions of the country [18] and many specialized diagnostic tests are unavailable or expensive. A trial of oral iron therapy is the subject of an ongoing study in our department.

\section{Conclusions and recommendations}

A state of iron deficiency may be present in SCD patients particularly in those without a history of blood transfusion. Therefore we recommend that nontransfused patients with SCD should be screened for iron deficiency by a battery of conventional laboratory tests.

\section{Acknowledgements}

Many thanks to Ms Lina Kassim who collaborated in performing some of the required laboratory analysis in the biochemistry laboratory of the Faculty of Medicine at University of Taiz

\section{References}

1. Iron deficiency and iron deficiency anemia. In: Lee GR, et al. Wintrobe's clinical hematology, volume 2, 10th ed. Baltimore, Maryland, Williams and Wilkins, 1999:979-1010.

2. Davies S, Henthorn J, Brozović M. Iron deficiency in sickle cell anemia. Journal of Clinical Pathology, 1983, 36:1012-1015.

3. Vichinsky $\mathrm{E}$ et al. The diagnosis of iron deficiency anemia in sickle cell disease. Blood, 198, 58(5):963-968.

4. King L, Reid M, Forrester TE. Iron deficiency anemia in Jamaican children, aged 1-5 years, with sickle cell disease. West Indian Medical Journal, 2005, 54(5):192-198.

5. Jackson RT, Al-Mousa Z. Iron deficiency is a more important cause of anemia than hemoglobinopathies in Kuwait adolescent girls. Journal of Nutrition, 2000, 130:1212-1216.

6. The prevalence of anaemia in women: a tabulation of available information, 2nd ed. Geneva, World Health Organization, 1992.

7. Mohanty D et al. Iron deficiency anemia in sickle cell disorders in India. Indian Journal of Medical Research, 2008, 127:366-369.

8. Lozoff B, Jimenez E, Wolf AW. Long-term developmental outcome of infants with iron deficiency. New England Journal of Medicine, 1991, 325:687-694.

9. International Committee for Standardization in Haematology. Recommendations for neonatal screening for haemoglobinopathies. Clinical and Laboratory Haematology, 1988, 10:335-345.
10. Riou J et al. Cation-exchange HPLC evaluated for presumptive identification of hemoglobin variants. Clinical Chemistry, 1997, 43:34-39.

11. Dallman PR, Siimes MA. Percentile curves for hemoglobin and red cell volume in infancy and childhood. Journal of Pediatrics, 1979, 94:26-31.

12. O'Brien RT. Iron burden in sickle cell anemia. Journal of Pediatrics, 1978, 92:579-582.

13. Serjeant GR et al. The development of hematological changes in homozygous sickle cell disease: a cohort study from birth to 6 years. British Journal of Haematology, 1981, 69:337340 .

14. Okeahialam TC, Obi GO. Iron deficiency in sickle cell anemia in Nigerian children. Annals of Tropical Paediatrics, 1982, 2:89-92.

15. Neve $V$ et al. Reference and cut-off values for serum ferritin, mean cell volume, and hemoglobin to diagnose iron deficiency in infants aged 9 to 12 months. Medicina (Kaunas), 2007, 43(9):698-702.

16. Das PK et al. Iron in sickle cell disease. Journal of the Association of Physicians of India, 1990, 38:847-849.

17. Rao Nagaraj J, Sur AM. Iron deficiency in sickle cell disease. Acta Paediatrica Scandinavica, 1980, 69:337-340.

18. Al-Nood $\mathrm{H}$ et al. Prevalence of the sickle cell gene in Yemen: a pilot study. Hemoglobin, 2004, 28(4):305-315. 